\title{
Case Overview of Patients under Surveillance of COVID-19 in Central Java Province, Indonesia
}

\author{
Dwi Sutiningsih ${ }^{1 *}$, Aufiena Nur Ayu Merzistya ${ }^{1}$, Yulianto Prabowo $^{2}$, Aris Sugiharto $^{2}$, Mufti \\ Agung Wibowo ${ }^{2}$ \\ ${ }^{1}$ Master of Epidemiology, Postgraduate School, Imam Barjo No. 5 Semarang, Indonesia \\ ${ }^{2}$ Department of Health, Central Java Province, Piere Tendean No. 24 Semarang, Indonesia
}

\begin{abstract}
Central Java reported 1,541 cases of Patients Under Surveillance until April 14th, 2020. It is expected to increase everyday. However, reports about the epidemiological characteristics of Patients Under Surveillance cases are still limited. This study aims to describe Patients Under Surveillance case of COVID-19. The study used quantitative descriptive design, whereas many as 1,541 cases were described based on the characteristics, contact history, history of transit, and the symptoms. The data are obtained from the Department of Health, Central Java and processed with descriptive statistical data analysis. Results showed from 1,541 cases as much as $59.9 \%$ were male and $43 \%$ aged 19-44 years. As many as 154 death cases were dominated by men $(61.6 \%)$ and elderly $\geq 60$ years $(38.3 \%)$. The highest IR was Semarang (16.85/100,000 population). Symptoms that often found were cough, fever, dyspnea $(8.3 \%)$, and $3.96 \%$ asymptomatic. The history of contact with the traveling person (4.7\%). The most visited city was Jakarta (7.5\%). It is concluded that cases in Central Java spread across 35 cities with a high number of cases and mortality. It is necessary to conduct a detailed Patients Under Surveillance case reports to monitor the spread of the virus that can be prevented in advance.
\end{abstract}

Keywords. COVID-19, Patients under Surveillance, PDP, Descriptive

\section{Introduction}

At the end of December 2019 in Wuhan City, Hubei Province, China, a new outbreak occurred and was designated as Coronavirus Diseases (COVID-19) [1, 2]. This disease is called COVID-19 because it is caused by coronavirus type 2 (SARS-CoV-2) which attacks the human respiratory tract [2]. It started from wild animals (bats) infected with coronavirus transmitted to humans and humans transmitted to other humans through droplets. This epidemic quickly spread internationally to other countries [3]. Therefore, on March 11,

* Corresponding author: dwi.sutiningsih@live.undip.ac.id 
2020, the World Health Organization (WHO) officially declared COVID-19 as a global pandemic [4].

The total of 10,695,608 cases of COVID-19 is recorded globally up to July $2^{\text {nd }}, 2020$, in 188 countries. Deaths recorded in the world were 508,055 cases, which means that the global Case Fatality Rate (CFR) was $21.05 \%$ [5, 6]. WHO established the assessment regarding the risk of spread and the impact of COVID-19 is very high at the global level [7]. The estimated reproduction number $\left(\mathrm{R}_{0}\right)$ of COVID-19 is 1.4 to 2.5 which means that a person with COVID-19 can transmit 1 to 2 people in the vicinity if efforts to prevent were not taken [8]. But this number is different from other studies, which estimates the $\mathrm{R}_{0}$ of COVID-19 is greater, which is 3.28 [9]. Indonesia is one of 188 countries that have contributed to COVID-19 cases in the world. Total cases of COVID-19 until July $2^{\star x}, 2020$, were confirmed at 57,770 positive cases with 25,595 recoveries, and 29,241 cases of death [10].

It is not only the confirmed positive cases that become concerned now but also the case with alleged COVID-19 or the so-called suspected COVID-19 is getting attention. The Ministry of Health in Indonesia set the terms suspect COVID-19 with the designation of Patients under Surveillance (in Bahasa: Pasien Dalam Pengawasan (PDP)). PDP is a person with ARI infection having symptoms or a history of fever $\left(\geq 38^{\circ} \mathrm{C}\right)$ accompanied by one of the COVID-19 symptoms, such as coughing, fatigue, loss of appetite, etc., have a history of travel to areas that are infected or history contact with COVID-19 patients, and no other causes by clinical overview [11]. Furthermore, PDP will take further tests to be determined as a positive or probable case of COVID-19 [12].

The number of PDP in Indonesia is reported as many as 13,296 patients and these cases are spread in 34 provinces in Indonesia [10]. Central Java is one of the provinces with the most cases of positive COVID-19 and PDP in Indonesia, occupying the top 4 . The data reported until April 14 ${ }^{\mathrm{t}}, 2020$ was 1,541 patients with PDP status in Central Java. The number of patients who died with PDP status was 154 patients, where $38.3 \%$ were people with age ( $\geq 60$ years) [13]. Reports on the epidemiological characteristics of PDP cases are still limited. This research aims to describe the characteristics, contact history, travel history, and symptoms of PDP of COVID-19 patients in Central Java. It is expected that the results of the study become a source of information to the public regarding the case of COVID-19, especially the case of the PDP of COVID-19 in the Central Java Province.

\section{Method}

This research used the descriptive quantitative design, in which we described the distribution of PDP cases of COVID-19 in Central Java that was reported until April 14", 2020. We recorded 1,541 cases of Patients Under Surveillance (PDP) COVID-19 spread over 35 cities/regencies in Central Java. The distribution of PDP cases is described based on the characteristics of the patients including age, gender, and region (city/district) origin and contact history, travel history, and the symptoms experienced. 154 cases PDP deaths described by the characteristics of age and gender. The data sources derived from case reports of PDP of COVID-19 by the Department of Health in Central Java and analyzed using descriptive statistical analysis to obtain the distribution of frequencies in each variable.

\section{Results}

\subsection{PDP Case Distribution based on gender}


The number of PDP cases of COVID-19 in Central Java is presented in Figure 1. In the graph, it shows that the incidence of PDP in male patients was more frequent than in females. There were 923 male patients with PDP status while there are 618 female patients. Similarly, the number of death cases of PDP patients. The death case of male amounted to 95 cases tends to be more compared to females with 59 cases.

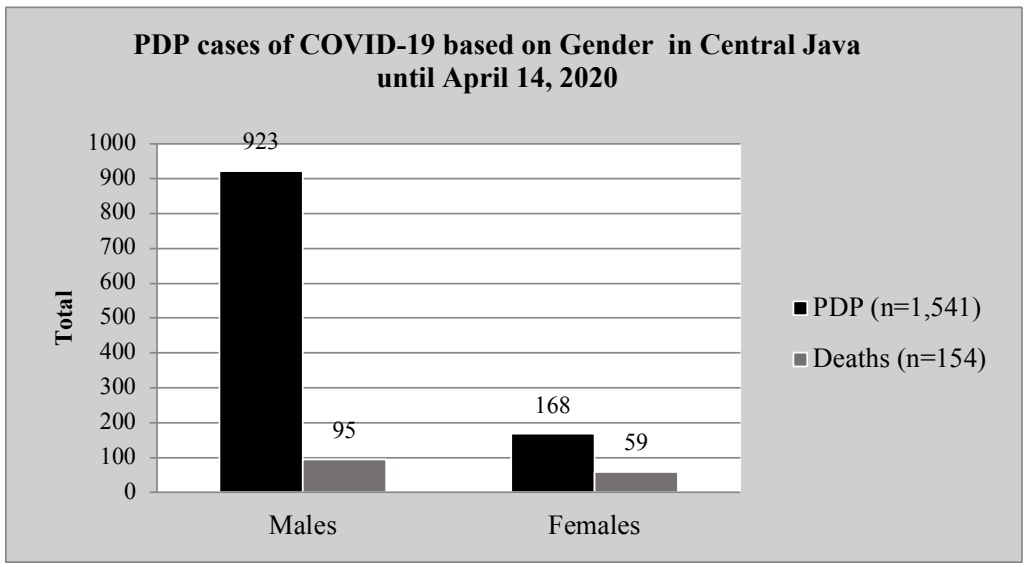

Fig. 1. Frequency distribution of PDP of COVID-19 in Central Java-based on gender

\subsection{PDP Case Distribution based on Age}

Patients suspected to COVID-19 or referred to as PDP occurs at all levels of age. The PDP case distribution and PDP death cases based on age are presented in graph 2 below. The graph shows that PDP cases most likely to happen at the reproductive age of 19-44 years old (adult) with 663 cases or $43 \%$ of total cases. It has the least happened in patients aged 6-9 years amounted to 25 children.

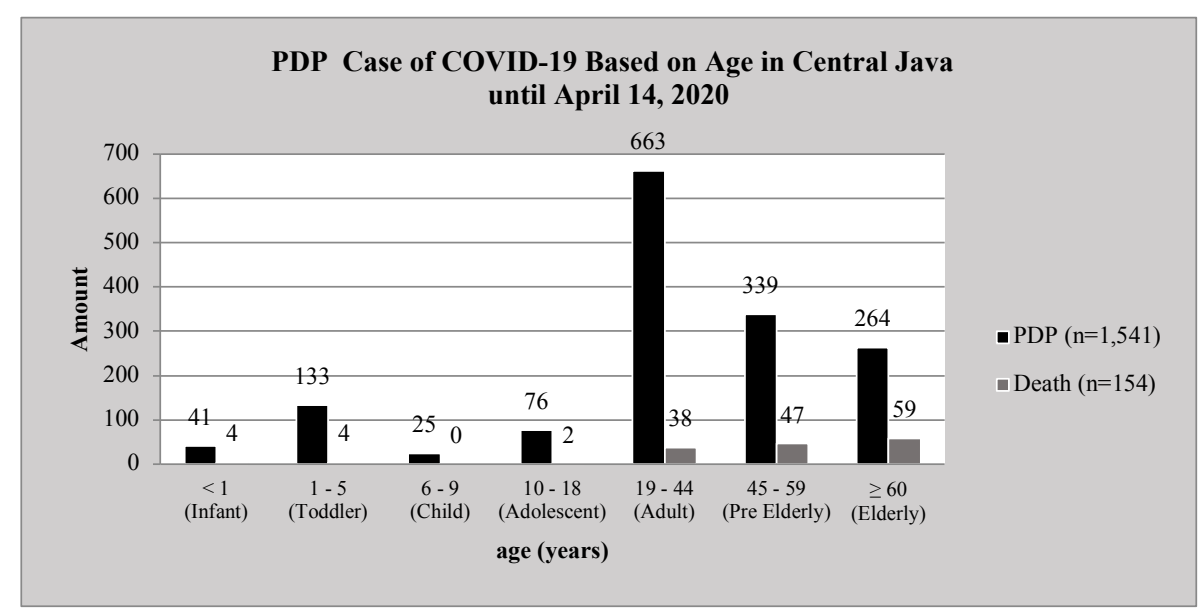

Fig. 2. The distribution of PDP COVID-19 frequencies in Central Java is based on age

In total 154 cases of death, the highest incidence occurred in elderly patients aged $(\geq 60$ years). A total of 59 patients $(38.3 \%)$ with elderly age died before the results of the test were out or still in the status of PDP. The lowest mortality rate was in the adolescent group 
(10-18 years) with 2 cases of death. No death cases occur in children by the age of 6-9 years.

\subsection{Distribution of PDP Cases by Origin}

PDP cases were spread in 35 cities/regencies in Central Java Province. The case distribution by the origin of the patients is presented in Table 1 . Seen from the table, that the highest case of PDP located in the city of Semarang with 306 cases (19.5\%). Semarang City's Incidence Rate (IR) was also the highest in Central Java at 16.85/100,000 population. In every 100,000 populations, there were at least 16 cases of PDP in Semarang that recorded until April 14, 2020. Besides, other higher IR occupied by Magelang with $15.59 / 100,000$ population. The region with the least number of PDP cases was Pekalongan with 3 PDP cases with IR of $0.99 / 100,000$ population. However, the lowest IR was in the Blora with IR of $0.70 / 100,000$ population with the case of the PDP as many as 6 patients.

Table 1. The frequency distribution of PDP COVID-19 cases based on Patients' origin in Central Java until April 14" 2020

\begin{tabular}{|c|c|c|c|c|c|}
\hline \multirow{2}{*}{ No } & \multirow{2}{*}{ District/City } & \multicolumn{2}{|c|}{ Total } & \multirow{2}{*}{$\begin{array}{c}\text { Total } \\
\text { Population* }\end{array}$} & \multirow{2}{*}{ IR/100,000 } \\
\hline & & Frequency & $\%$ & & \\
\hline 1. & Semarang & 301 & 19.5 & $1,786,114$ & 16.85 \\
\hline 2. & Magelang City & 19 & 1,2 & 121,872 & 15.59 \\
\hline 3. & Surakarta & 62 & 4.0 & 517,887 & 11.97 \\
\hline 4. & Kudus & 82 & 5,3 & 861,430 & 9.52 \\
\hline 5. & Salatiga & 17 & 1,1 & 191,571 & 8.87 \\
\hline 6. & Purbalingga & 76 & 4.9 & 925,193 & 8.21 \\
\hline 7. & Tegal & 17 & 1,1 & 249,003 & 6.83 \\
\hline 8. & Karanganyar & 42 & 2.7 & 879,078 & 4.78 \\
\hline 9. & Banyumas & 80 & 5.2 & $1,679,124$ & 4.76 \\
\hline 10. & Demak & 54 & 3.5 & $1,151,796$ & 4.69 \\
\hline 11. & Magelang & 59 & 3.8 & $1,279,625$ & 4.61 \\
\hline 12. & Sukoharjo & 40 & 2.6 & 885,205 & 4.52 \\
\hline 13. & Purworejo & 30 & 1.9 & 716,477 & 4.19 \\
\hline 14. & Semarang & 42 & 2.7 & $1,040,629$ & 4.04 \\
\hline 15. & Banjarnegara & 34 & 2.2 & 918,219 & 3.70 \\
\hline 16. & Brebes & 61 & 4.0 & $1,802,829$ & 3.38 \\
\hline 17. & Rembang & 21 & 1,4 & 633,584 & 3.31 \\
\hline 18. & Wonosobo & 26 & 1.7 & 787,384 & 3.30 \\
\hline 19. & Cilacap & 52 & 3,4 & $1,719,504$ & 3.02 \\
\hline 20. & Tegal & 43 & 2.8 & $1,437,225$ & 2.99 \\
\hline 21. & Kebumen & 35 & 2,3 & $1,195,092$ & 2.93 \\
\hline 22. & Wonogiri & 28 & 1.8 & 957,106 & 2.93 \\
\hline 23. & Jepara & 36 & 2,3 & $1,240,600$ & 2.90 \\
\hline 24. & Sragen & 25 & 1.6 & 887,889 & 2.82 \\
\hline 25. & Kendal & 24 & 1.6 & 964,106 & 2.49 \\
\hline 26. & Boyolali & 24 & 1.6 & 979,799 & 2.45 \\
\hline 27. & Batang & 15 & 1,0 & 762,377 & 1.97 \\
\hline 28. & Klaten & 23 & 1.5 & $1,171,411$ & 1.96 \\
\hline 29. & Pati & 24 & 1.6 & $1,253,299$ & 1.91 \\
\hline 30. & Grobogan & 25 & 1.6 & $1,371,610$ & 1.82 \\
\hline
\end{tabular}




\begin{tabular}{|c|l|r|r|r|r|}
\hline 31. & Pemalang & 20 & 1,3 & $1,299,724$ & 1.54 \\
\hline 32. & Temanggung & 10 & 0.6 & 765,594 & 1.31 \\
\hline 33. & Pekalongan & 9 & 0.6 & 891,892 & 1.01 \\
\hline 34. & Pekalongan City & 3 & 0.2 & 304,477 & .99 \\
\hline 35. & Blora & 6 & 0.4 & 862,110 & 0.70 \\
\hline 36. & Central Java & 76 & 4.9 & - & - \\
\hline Total & $\mathbf{1 . 5 4 1}$ & $\mathbf{1 0 0 . 0}$ & - & - \\
\hline
\end{tabular}

* BPS data for Central Java in 2018

\subsection{PDP Case Distribution Based on Symptoms Experienced}

The symptoms experienced in the PDP case are presented in Table 2. The table shows that the symptoms are often found that are fever, cough, and dyspnea with $8.3 \%$ of the total 1,541 cases. Besides, symptoms with cough and fever alone are also commonly found in PDP cases as much as $6.1 \%$. The case of asymptomatic patients pretty much found also in Central Java. A total of $3.96 \%$ or 61 people registered without any symptoms when doing checks at health facilities in Central Java. Even so, $41.73 \%$ of the patients were not recorded in the report.

Table 2. The frequency distribution of symptoms experienced by the PDP COVID-19 in Central Java until April 14 ${ }^{\text {th }}, 2020$

\begin{tabular}{|l|r|r|}
\hline Symptoms experienced & Frequency & \multicolumn{1}{|c|}{$\%$} \\
\hline Cough & 47 & 3.05 \\
\hline Bleeding cough & 4 & 0.26 \\
\hline Cough, cephalgia, fever & 14 & 0.91 \\
\hline Cough, cephalgia, dyspnea, & 3 & 0.19 \\
\hline Cough, cephalgia, sore throat & 2 & 0.13 \\
\hline Cough, cephalgia, cold & 2 & 0.13 \\
\hline Cough, fever & 94 & 6.10 \\
\hline Cough, fever, diarrhea & 8 & 0.52 \\
\hline Cough, fever, dyspnea & 128 & 8.31 \\
\hline Cough, fever, dyspnea, colds & 51 & 3.31 \\
\hline Cough, fever, malaise & 7 & 0.45 \\
\hline Cough, fever, colds & 70 & 4.54 \\
\hline Cough, fever, nausea & 11 & 0.71 \\
\hline Cough, fever, sore throat & 14 & 0.91 \\
\hline Cough, fever, sore throat, cold & 19 & 1.23 \\
\hline Cough, fever, odynophagia & 9 & 0.58 \\
\hline Cough, diarrhea & 2 & 0.13 \\
\hline Cough, dyspnea & 69 & 4.48 \\
\hline Cough, dyspnea, sore throat & 7 & 0.45 \\
\hline Cough, dyspnea, odynophagia & 2 & 0.13 \\
\hline Cough, dyspnea, colds & 9 & 0.58 \\
\hline Cough, Cold & 3 & 0.19 \\
\hline Cough, malaise & 36 & 2.34 \\
\hline Cough, sore throat & 10 & 0.65 \\
\hline Cough, odynophagia & 3 & 0.19 \\
\hline Cephalgia, fever & 10 & 0.65 \\
\hline Fever & 58 & 3.76 \\
\hline
\end{tabular}




\begin{tabular}{|l|r|r|}
\hline Fever, diarrhea & 3 & 0.19 \\
\hline Fever, dyspnea & 36 & 2.34 \\
\hline Fever, dyspnea, malaise & 3 & 0.19 \\
\hline Fever, dyspnea, sore throat & 4 & 0.26 \\
\hline Fever, dyspnea, odynophagia & 2 & 0.13 \\
\hline Fever, nausea, vomiting & 20 & 1.30 \\
\hline Fever, sore throat & 7 & 0.45 \\
\hline Fever, colds & 3 & 0.19 \\
\hline Dyspnea & 38 & 2.47 \\
\hline Edema pulmonary, breathing difficulties & 1 & 0.06 \\
\hline breathing difficulties, shock & 1 & 0.06 \\
\hline Limp & 2 & 0.13 \\
\hline Malaise & 6 & 0.39 \\
\hline Shivers, sore throat & 1 & 0.06 \\
\hline Nausea, Vomiting & 1 & 0.06 \\
\hline Nausea, Vomiting, Stomach Pain & 1 & 0.06 \\
\hline Vomiting, chest pain & 1 & 0.06 \\
\hline Stomach Pain & 2 & 0.13 \\
\hline Low back pain & 1 & 0.06 \\
\hline Throat Pain & 4 & 0.26 \\
\hline Odynophagia, Cold & 1 & 0.06 \\
\hline Decreased Consciousness & 1 & 0.06 \\
\hline Pneumonia & 1 & 0.06 \\
\hline Dizzy & 2 & 0.13 \\
\hline Cold & 2 & 0.13 \\
\hline Itchy Throat & 1 & 0.06 \\
\hline No symptoms & 61 & 3.96 \\
\hline Not Recorded & 643 & 41.73 \\
\hline Total & $\mathbf{1 . 5 4 1}$ & 100.00 \\
\hline & & \\
\hline
\end{tabular}

\subsection{PDP Cases Distribution Based on Contact History}

Contact History of PDP patients in Central Java is shown in Table 3. A total of 72 patients with the status of PDP had a history of contact with travelers. Contact history is the most frequently happened in the case of PDP in Central Java. Travelers are people who traveled from the country or region that had been reported to be exposed to COVID-19 [14]. Nevertheless, as many as 1,276 PDP patients (82.8\%) had no clear or recorded contact history so the definite history of contact of the patients before being declared as PDP cannot be concluded.

Table 3. The frequency distribution of contact history of PDP COVID-19 in Central Java until April $14^{\text {in }}, 2020$

\begin{tabular}{|l|r|r|}
\hline Contact History & Frequency & \multicolumn{1}{|c|}{$\%$} \\
\hline Contact History with people under surveillance & 7 & 0.5 \\
\hline Contact History with the foreigners & 5 & 0.3 \\
\hline Contact History with asymptomatic patients & 1 & 0.1 \\
\hline Contact History with positive COVID-19 patients & 33 & 2.1 \\
\hline Contact History with PDP & 41 & 2.7 \\
\hline Contact History with Travelers & 72 & 4.7 \\
\hline
\end{tabular}




\begin{tabular}{|l|r|r|}
\hline Secondary Contact History with the foreigners & 1 & 0.1 \\
\hline Secondary Contact History with positive COVID-19 patients & 1 & 0.1 \\
\hline Secondary Contact History with Travelers & 1 & 0.1 \\
\hline No contact history & 103 & 6.7 \\
\hline Contact history is unclear & 1,276 & 82.8 \\
\hline Total & $\mathbf{1 , 5 4 1}$ & $\mathbf{1 0 0 . 0}$ \\
\hline
\end{tabular}

\subsection{PDP Cases Distribution Based on Travel History}

Based on Table 4 presented below, it is figured that most patients (25.9\%) with the status of PDP had a domestic trip and as much as $3.2 \%$ or 50 PDP patients traveled overseas. However, as much as $61.5 \%$ is not known clearly or not recorded in a report regarding their travel history before being declared as PDP. This number was bigger compared with the data recorded so that the travel history of PDP patients could not be concluded.

Table 4. Frequency distribution of PDP COVID-19 travel history in Central Java until April $14^{\text {th }}$, 2020

\begin{tabular}{|l|r|r|}
\hline Travel History & Frequency & \multicolumn{1}{|c|}{ \% } \\
\hline Domestic Travel history & 399 & 25.9 \\
\hline Overseas Travel history & 50 & 3,2 \\
\hline Domestic and Overseas Travel history & 1 & 0.1 \\
\hline Unclear Travel history & 947 & 61.5 \\
\hline No travel history & 144 & 9.3 \\
\hline Total & $\mathbf{1 , 5 4 1}$ & $\mathbf{1 0 0 . 0}$ \\
\hline
\end{tabular}

\subsection{PDP Cases Distribution Based on Transit Place}

Transit history is a place or area that had been visited by the PDP during the 14 days before experiencing symptoms of COVID-19. The distribution of PDP cases based on transit place is presented in Table 5 below.

Table 5. Frequency distribution of PDP COVID-19 transit history in Central Java until April 14, 2020

\begin{tabular}{|c|c|c|c|c|c|}
\hline Transit & Frequency & $\%$ & Transit & Frequency & $\%$ \\
\hline Ajibarang & 1 & 0.06 & Colombus Ship & 1 & 0.06 \\
\hline America & 1 & 0.06 & Karawang & 1 & 0.06 \\
\hline Australia & 1 & 0.06 & Kediri & 1 & 0.06 \\
\hline Australia, Malaysia & 1 & 0.06 & Klampok & 1 & 0.06 \\
\hline Bali & 1 & 0.06 & Klaten & 2 & 0.12 \\
\hline Bandung & 1 & 0.06 & Korea & 5 & 0.32 \\
\hline $\begin{array}{l}\text { Bandung, } \\
\text { Jakarta, Purwokerto }\end{array}$ & 1 & 0.06 & Kudus & 3 & 0.19 \\
\hline Banten & 1 & 0.06 & Magelang & 6 & 0.39 \\
\hline Banyuwangi & 1 & 0.06 & Magetan & 1 & 0.06 \\
\hline Batam & 1 & 0.06 & Makasar & 9 & 0.58 \\
\hline Bekasi & 1 & 0.06 & $\begin{array}{l}\text { Makasar, } \\
\text { Surabaya }\end{array}$ & 2 & 0.12 \\
\hline Bogor & 1 & 0.06 & Malang & 4 & 0.26 \\
\hline
\end{tabular}




\begin{tabular}{|c|c|c|c|c|c|}
\hline $\begin{array}{l}\text { Bogor, Madiun, Merak, } \\
\text { Solo }\end{array}$ & 1 & 0.06 & Malaysia & 8 & 0.50 \\
\hline Boyolali & 1 & 0.06 & $\begin{array}{l}\text { Malaysia, } \\
\text { Singapore }\end{array}$ & 1 & 0.06 \\
\hline Boyolali, Jakarta & 1 & 0.06 & Maluku & 1 & 0.06 \\
\hline Cengkareng & 1 & 0.06 & Merauke & 1 & 0.06 \\
\hline Ciamis & 1 & 0.06 & Palembang & 2 & 0.12 \\
\hline Cikarang & 1 & 0.06 & Papua & 1 & 0.06 \\
\hline Cilacap & 1 & 0.06 & Pati & 4 & 0.26 \\
\hline Cilegon & 1 & 0.06 & Pekalongan & 3 & 0.19 \\
\hline China & 1 & 0.06 & Purbalingga & 1 & 0.06 \\
\hline Cirebon & 1 & 0.06 & Rembang & 2 & 0.12 \\
\hline $\begin{array}{l}\text { Cirebon, } \\
\text { Jakarta, Purbalingga }\end{array}$ & 1 & 0.06 & Salatiga & 4 & 0.26 \\
\hline Depok & 8 & 0.50 & Saudi Arabia & 13 & 0.84 \\
\hline Dubai, Europe & 1 & 0.06 & Semarang & 50 & 3.24 \\
\hline Garut & 1 & 0.06 & Singapore & 5 & 0.32 \\
\hline Gowa & 8 & 0.50 & Solo & 26 & 1.69 \\
\hline Gowa , Makassar & 1 & 0.06 & Solo, Yogyakarta & 1 & 0.06 \\
\hline Jakarta & 116 & 7.53 & Sukabumi & 7 & 0.45 \\
\hline Jakarta, Kalimantan & 1 & 0.06 & Sukoharjo & 2 & 0.12 \\
\hline Jakarta, Makassar & 1 & 0.06 & South Sulawesi & 1 & 0.06 \\
\hline Jakarta, Palembang & 1 & 0.06 & Sumatra & 1 & 0.06 \\
\hline Jakarta, Surabaya & 1 & 0.06 & Surabaya & 17 & 1.10 \\
\hline West Java & 1 & 0.06 & Taiwan & 1 & 0.06 \\
\hline Jember & 1 & 0.06 & Tangerang & 16 & 1.04 \\
\hline Japan & 5 & 0.32 & Tegal & 1 & 0.06 \\
\hline Japan, Yogyakarta & 1 & 0.06 & Wonogiri & 1 & 0.06 \\
\hline Jepara & 2 & 0.12 & Yogyakarta & 16 & 1.04 \\
\hline Jepara, Kendal & 1 & 0.06 & $\begin{array}{l}\text { There } \\
\text { was history but } \\
\text { unclear location }\end{array}$ & 12 & 0.78 \\
\hline Jombang & 1 & 0.06 & No history & 44 & 9.34 \\
\hline Juwana & 1 & 0.06 & Not recorded & 947 & 61.45 \\
\hline Central Kalimantan & 1 & 0.06 & Total & 1,541 & 100.00 \\
\hline
\end{tabular}

Based on the table above, note that the most visited transit by the PDP in Central Java is Jakarta with 7,53\%. Other regions that were visited by the patient before being declared as PDP are mostly to Semarang (3.24\%) and Solo (1.69\%). Even so, there was still quite a lot of transit history by PDP which was not recorded as many as 947 cases $(61.45 \%)$, cases and locations of transit were not clear $(0.78 \%)$. Therefore, we cannot precisely conclude the transit places of PDP in the province of Central Java.

\section{Discussion}

A total of 1,541 patients suspected with COVID-19 classified as PDP cases in Central Java. Among the 1,541 cases, $43 \%$ were patients aged $19-44$ years with male patients (59.9\%), a bigger number than in females. The result is similar to a study in Nepal which found that 
out of 40 patients with suspected COVID-19, 62.5\% of the patients are males with the range of an average age of 24-44 years [15]. Similar to the other studies showed that the number of cases with males who are infected from experiencing severe symptoms is bigger compared to females [16]. From 425 patients with COVID-19, 56\% are males $[17,18]$. Besides, the average age of the patients infected with COVID-19 is 45-56 years [19-21]. It is contrary to the results of the study found in China, where cases of suspected and confirmed are more found in females (72.9\%) compared to males with an average age of 39.08 years [22].

The death case of PDP in Central Java are 154 cases, where the proportion of males still dominates the number. There are more elderly patients age $\geq 60$ years $(38.3 \%)$ than other ages. Similar cases were reported in a study in China, the percentage of older age $(\geq 65$ years) was found far higher in deceased patients than in cured patients $(83.8 \%$ in 37 patients who deceased compared to $13.2 \%$ in 1,019 cured patients) [23]. In the elderly, the severity of death is more susceptible. Death in the elderly PDP might be influenced by other factors including comorbidities such as diabetes, hypertension, and coronary heart disease [24, 25].

Both the males and females have the same risk to be PDP, positive COVID-19, or vulnerable to death from COVID-19. It is described in a study in China, where vulnerability to the same proportion happened in 1,019 patients, $50 \%$ in males, and $50 \%$ in females. The gender factors and the tendency of the number of males that are bigger in this incident, it can be associated with shorter life expectancy in men than women in China and some other countries in general [23].

Symptoms that are often found in PDP cases include coughing, fever, and dyspnea. WHO explained that some people who are infected with COVID-19 will experience mild to moderate symptoms associated with respiratory or recover without treatment [26]. Common symptoms that often occur are a fever with temperature $>37.8^{\circ} \mathrm{C}$, fatigue, and dry cough. Other symptoms such as short breath, myalgia, sore throat, dyspnea, pneumonia, and some people reported diarrhea, nausea, or colds, pulmonary edema, failure of many organs [18, 26-28]. Even at this time, there are many cases of asymptomatic people in PDP cases that have become positive COVID-19. In this study 61 patients $(3.96 \%)$ found without symptoms. It is similar to findings in a study in Japan, $41 \%$ of the total 104 patients were known to be asymptomatic [29]. Other studies report 2 of 78 confirmed as cases with no symptoms [30]. There is a claim in a study that there is no statistical difference between the transmissibility of asymptomatic cases compared with the symptomatic cases [31]. However, based on a re-analysis of other studies it is known that the transmissibility of asymptomatic cases can be lower than symptomatic cases by comparing reproduction rates [32].

The Semarang City is the area with the highest PDP case in Central Java. The high number of residents as well as the high activity in Semarang as the Capital City of Central Java became one of the contributing factors of the increase in COVID-19. In handling COVID-19, the government has made efforts to reduce the number of COVID-19 cases in Semarang by implementing a program called Community Activity Restrictions. This program is a policy in limiting activities such as work, school, and other gathering activities in the community to reduce the spread of the COVID-19 virus which is increasingly widespread in the Semarang [33].

The restrictions had been implemented because of the rapid spread of the virus through direct contact with the people who are infected with COVID-19. Transmission of COVID19 from human to human is through droplets when talking/sneezing/coughing [34]. In this database, as many as 162 cases of PDP recorded had a history of contact with people who allegedly can transmit COVID-19. The case of PDP in Central Java had most contact history with the traveler, amounted to 72 cases of PDP. Travelers are those who travel to 
areas confirmed to be exposed to COVID-19 [14]. Studies in Nepal explained that one of the four patients who were treated had a history of contact with members of the family who are asymptomatic or people without symptoms (in Bahasa: Orang Tanpa Gejala (OTG)) that recently returned from India [15]. It also supported by another study in China, where 24 OTG patients transmit to family members who live in one house and show the severity of COVID-19 infection [21].

The reports on the contact history of PDP patients need to be made to determine the exposure to the virus obtained from the patient as well as information in tracing to prevent increasingly widespread transmission. This contact history can be a factor in patients experiencing symptoms or infected by COVID-19. Rapid transmission of COVID-19 makes it easy for widespread transmission in an area. Estimated reproduction number (R0) of COVID-19 by 1.4 to 2.5 which means that a person with COVID-19 can transmit 1 to 2 people in the vicinity if prevention efforts are not taken [8]. However, this number is different from other researches that estimating the R0 of COVID-19 is greater that is 3.28 [9].

\section{Conclusions}

The case of the PDP COVID-19 in Central Java recorded as many as 1,541 cases with 154 deaths until April 14, 2020. In this case, the category of age with most patients are 19-44 years, while the most death of a patient of PDP found in elderly patients ( $\geq 60$ years old). Death cases of PDP can be caused by factors like comorbidities and others. Semarang became the area with the highest IR in Central Java, so the government immediately carry out the Community Activity Restriction to reduce the crowded activity of the people and to prevent the transmission of COVID-19 that increasingly widespread in Semarang. It is because the transmission of COVID-19 is rapid and direct contact from human to human. Besides, the reports on unclear contact history are still dominating. The most visited transit in Jakarta, but there are more data unrecorded. Symptoms that most commonly found include fever, cough, and dyspnea. It is necessary to make a precise and clear report on contact or transit history in PDP cases to determine the possibility of exposure to the virus of the patients obtained from contact with other people as well as information to perform tracing to prevent wider transmission. This research is expected to be a source of information and input for related institute to put into consideration in making an effective policy so that the transmission of COVID-19 is not getting wider and the cases are not increased in Central Java.

\section{Acknowledgement}

We would like to convey our gratitude to the Department of Health, Central Java Province that has been giving permission and cooperation in carrying out the study so that it can run smoothly. We would also like to convey our gratitude to Masters of Epidemiology, Postgraduate School, Diponegoro University in Semarang that gives permission and support in conducting this research.

\section{References}

1. WHO. WHO Statement Regarding Cluster of Pneumonia Cases in Wuhan China [Internet]. World Health Organization. (2020) [cited 2020 Mar 19]. Available from: https://www.who.int/china/news/detail/09-01-2020-who-statement-regarding-clusterof-pneumonia-cases-in-wuhan-china

2. WHO. Naming the coronavirus disease (COVID-19) and the virus that causes it. 
Coronavirus disease 2019. (2020).

3. WHO. Statement on the second meeting of the International Health Regulations (2005) Emergency Committee regarding the outbreak of novel coronavirus (2019-nCoV) [Internet]. World Health Organization. 2020 [cited 2020 Apr 26]. Available from: https://www.who.int/news-room/detail/30-01-2020-statement-on-the-second-meetingof-the-international-health-regulations-(2005)-emergency-committee-regarding-theoutbreak-of-novel-coronavirus-(2019-ncov)

4. WHO. WHO Director-General's opening remarks at the media briefing on COVID19. Geneva; (2020).

5. WHO. Coronavirus Disease 2019 Situation Report - 163. Vol. 14, Coronavirus disease 2019. Geneva; (2020).

6. Johns Hopkins University (JHU). COVID-19 Dashboard by the Center for Systems Science and Engineering (CSSE) at Johns Hopkins University (JHU). New York; (2020).

7. WHO. WHO Director-General's opening remarks at the media briefing on COVID-19 - 28 February 2020. WHO Director-General. Geneva; (2020).

8. WHO. Statement on the meeting of the International Health Regulations (2005) Emergency Committee regarding the outbreak of novel coronavirus (2019-nCoV) Credits Statement on the meeting of the International Health Regulations (2005) Emerge. Newsroom. (2020).

9. Liu Y, Gayle AA, Wilder-Smith A, Rocklöv J. The reproductive number of COVID-19 is higher compared to SARS coronavirus. J Travel Med. 2020;27(2):1-4.

10. BNPB. Peta Sebaran. Jakarta; 2020.

11. Kemenkes. Pedoman Pencegahan dan Pengendalian Coronavirus Disease (Covid-19). Jakarta: Kementerian Kesehatan RI; 2020. 1-116 p.

12. Kemenkes RI. Surveilans, Karantina, dan Observasi Orang Terpapar Coronavirus Disease ( COVID-19). 2020;

13. Dinkes Provinsi Jateng. Data Kasus Pasien Dalam Pengawasan (PDP) di Provinsi Jawa Tengah. Semarang; 2020.

14. Kemenkes RI. Pedoman Pencegahan dan Pengendalian Coronavirus Disease (COVID19). Germas. Jakarta: Keme; 2020. 0-115 p.

15. Shrestha A, Bajracharya S. Clinical characteristics of suspected COVID-19 admitted to the isolation ward of Patan Hospital, Nepal. J Patan Acad Heal Sci. 2020;7(1):7-12.

16. Susilo A, Rumende CM, Pitoyo CW, Santoso WD, Yulianti M, Herikurniawan H, et al. Coronavirus Disease 2019: Tinjauan Literatur Terkini. J Penyakit Dalam Indones. 2020;7(1):45.

17. Li Q, Guan X, Wu P, Wang X, Zhou L, Tong Y, et al. Early transmission dynamics in Wuhan, China, of novel coronavirus-infected pneumonia. $N$ Engl $J$ Med. 2020;382(13):1199-207.

18. Wang D, Hu B, Hu C, Zhu F, Liu X, Zhang J, et al. Clinical Characteristics of 138 Hospitalized Patients With 2019 Novel Coronavirus-Infected Pneumonia in Wuhan, China. JAMA. 2020;323(11):1061-9.

19. Guan W, Ni Z, Hu Y, Liang W, Ou C, He J, et al. Clinical Characteristics of Coronavirus Disease 2019 in China W. N Engl J Med. 2020;382(18):1708-20.

20. Chan J, Yuan S, Kok K, To K, Chu H, J Y, et al. A Familial Cluster of Pneumonia Associated with the 2019 Novel Coronavirus indicating Perso-to-Person Transmission. Lancet. 2020;395:514-23.

21. Hu Z, Song C, Xu C, Jin G, Chen Y, Xu X, et al. Clinical characteristics of 24 asymptomatic infections with COVID-19 screened among close contacts in Nanjing, China. Sci China Life Sci. 2020;63(5):706-11.

22. Xu H, Huang S, Liu S, Deng J, Jiao B, Ai L, et al. Evaluation of the Clinical 
Characteristics of Suspected or Confirmed Cases of COVID-19 During Home Care with Isolation: A New Retrospective Analysis Based on O2O. SSRN Electron J. 2020;

23. Jin JM, Bai P, He W, Wu F, Liu XF, Han DM, et al. Gender Differences in Patients With COVID-19: Focus on Severity and Mortality. Front Public Heal. 2020;8(April):1-6.

24. Zhou F, Yu T, Du R, Ms GF, Liu Y, Liu Z, et al. Clinical course and risk factors for mortality of adult inpatients with COVID-19 in Wuhan, China : a retrospective cohort study. Lancet [Internet]. Elsevier Ltd; 2020;6736(March). Available from: http://dx.doi.org/10.1016/S0140-6736(20)30566-3

25. Li X, Xu S, Yu M, Wang K, Tao Y, Zhou Y. Risk factors for severity and mortality in adult COVID-19 inpatients in Wuhan. J Allergy Clin Immunol [Internet]. Elsevier Inc.; 2020;146(1):110-8. Available from: https://doi.org/10.1016/j.jaci.2020.04.006

26. WHO. Coronavirus [Internet]. 2020 [cited 2020 Jul 9]. Available from: https://www.who.int/emergencies/diseases/novel-coronavirus-2019

27. Hill B. Coronavirus: origins, signs, prevention and management of patients. Br J Nurs. 2020;29(7):399-402.

28. Fan Y, Cheng X, Xue G, Wu J, Huang Z. Spectrochimica Acta Part A : Molecular and Biomolecular Spectroscopy On the combination of luminescent rare earth MOF and rhodamine dopant with two sensing channels for picric acid. Spectrochim Acta Part A Mol Biomol Spectrosc [Internet]. Elsevier B.V.; 2019;213:210-7. Available from: https://doi.org/10.1016/j.saa.2019.01.037

29. Tabata S, Imai K, Kawano S, Ikeda M, Kodama T, Miyoshi K, et al. Clinical characteristics of COVID-19 in 104 people with SARS-CoV-2 infection on the Diamond Princess cruise ship : a retrospective analysis. Lancet Infect Dis [Internet]. Elsevier Ltd; 2020;3099(20):1-8. Available from: http://dx.doi.org/10.1016/S14733099(20)30482-5

30. Wan R, Mao Z, He L, Hu Y. International Journal of Infectious Diseases Evidence from two cases of asymptomatic infection with SARS-CoV-2: Are 14 days of isolation suf fi cient? Int J Infect Dis. 2020;95(2020):174-5.

31. Chen Y, Wang A, Yi B, Ding K, Wang H, Wang J. The Epidemiological Caharcteristic of Infection in close contact of COVID-19 in Ningbo City. Chinese J Epidemiol. 2020;41(5):667-71.

32. He D, Zhao S, Lin Q, Zhuang Z, Cao P, Wang MH, et al. International Journal of Infectious Diseases The relative transmissibility of asymptomatic COVID-19 infections among close contacts. Int J Infect Dis [Internet]. International Society for Infectious Diseases; 2020;94:145-7. Available from: https://doi.org/10.1016/j.ijid.2020.04.034

33. Mayor of Semarang. Keputusan Walikota Nomor 443/417 Tahun 2020 Tentang Pemberlakuan Pelaksanaan Pembatasan Kegiatan Masyarakat Dalam Rangka Percepatan Penanganan Corona Virus Desease 2019 (COVID 19) Di Kota Semarang [Internet]. Semarang; 2020. Available from: http://jdih.semarangkota.go.id/jdihanggota/www/index.php/web/result/1024/detail

34. Phan LT, Nguyen TV, Luong QC, Nguyen TV, Nguyen HT, Le HQ, et al. Importation and Human-to-Human Transmission of a Novel Coronavirus in Vietnam. New Engl $\mathbf{J}$ Med. 2020;382:872-4. 